Bonnie J. Miller-McLemore

\title{
Five Misunderstandings about Practical Theology ${ }^{1}$
}

Zusammenfassung: Inspiriert durch einen Aufsatz des Soziologen Bent Flyvbjerg über Fallstudien untersucht dieser Beitrag folgende fünf allgemeine Missverständnisse in der Geschichte und Entwicklung der Praktischen Theologie als akademischer Institution: (1) Praktische Theologie ist eine ausgegrenzte Disziplin in einer ernsthaften Identitätskrise. (2) Das Problem der Praktischen Theologie und theologischer Ausbildung ist das klerikale Paradigma. (3) Praktische Theologie und Pastoraltheologie sind austauschbare Begriffe. (4) Es ist unmöglich, Praktische Theologie zu definieren, oder, umgedreht, ist ganz einfach zu definieren (etwa als Untersuchung der Beziehung zwicschen Glauben und Handeln). (5) Praktische Theologie ist zum Teil oder als Ganze deskriptiv, empirisch, interpretativ, und nicht normative, theologisch, und, in bestimmter Hinsicht, christlich. Es werden alle Missverständnisse beschrieben, Korrekturmöglichkeiten vorgeschlagen und schließlich gefolgert, dass drei Jahrzehnte der Entwicklung auf diesem Feld und paralleler Prozesse anderer Bereiche der Wissenschaft es nahe legen, die ursprüngliche Intuition zu bestätigen, dass es einen alternativen Weg theologischen Denkens geben müsse und diese Disziplin daran weiter $\mathrm{zu}$ arbeiten hat.

Abstract: Borrowing a format used by sociologist Bent Flyvbjerg in an essay on case studies, this article examines five common misunderstandings in the history and development of scholarship in practical theology: (1) practical theology is a marginalized discipline with a serious identity crisis; (2) the problem with practical theology and theological education is the clerical paradigm; (3) practical and pastoral theology are interchangeable terms; (4) practical theology is impossible to define or, inversely, can be defined simply (e.g., study of the relationship between beliefs and practices); and (5) practical theology is largely, if not wholly, descriptive, empirical, interpretative, and not normative, theological, and in some cases (dare I say) Christian. I describe each misunderstanding,

1 This article is a slight revision and expansion of my Presidential Address at the International Academy of Practical Theology, July 25, 2011. I thank participants for comments and feedback. In examining the five misunderstandings, I bring together claims I have developed in more detail elsewhere for the sake of this article's larger argument about the discipline of practical theology as a whole. Footnotes credit these previous works and I remain grateful in particular to scholarly collaboration that continues to enrich my own reflection with Dorothy Bass, Kathleen Cahalan, Craig Dykstra, James Nieman, and Chris Scharen. 
offer correctives, and conclude that three decades of progress in the field and complementary developments in other areas of the academy affirm early intuitions in practical theology about the need for alternative ways of theological knowing and for further work in the discipline.

Bonnie J. Miller-McLemore: E. Rhodes and Leona B. Carpenter Professor of Pastoral Theology, The Divinity School and Graduate Department of Religion, Vanderbilt University, Nashville TN 37240, USA, Email: bonnie.miller-mclemore@vanderbilt.edu

I begin with gratitude. I experienced a joy in the presidency of the International Academy of Practical Theology (IAPT) that I had not expected. I had a real sense that members and the group as a whole had invested trust and authority in me to care for IAPT business. Maybe it was sabbatical, maybe turning 55, maybe editing two books in the field, all this put me into a position of unexpected appreciation for the Academy and our shared work - unexpected because normally one would avoid spoiling a sabbatical with administration. Instead the responsibility has enriched my life, and I have been grateful for the opportunity to serve.

This past year was bookmarked for me by Don Browning's death and its anniversary. He died in early June at the beginning of my sabbatical, shortly before I spoke at the US Society for Pastoral Theology, and I remembered his passing as I saw my sabbatical come to closure, collected my thoughts for this plenary, and anticipated our first conference without him. I am among the many who remain indebted to him, and I pause to remember him gratefully now.

The prospect of a presidential address has felt like a beacon ahead. What can I say to you that will promote our understanding of the discipline? Among the many thoughts I've had, this plenary represents what won out, a little like "what I saw on my way to the IAPT conference." It reminds me of the book by infamous children's author Dr. Seuss, And To Think I Saw it On Mulberry Streeta tale of all the fantastical sights a child sees on the way home, eventually reduced under the adult gaze to "a plain horse and a wagon." Seuss's book was rejected twenty-seven times (!) before a publisher took the risk; readers thought it lacked moral and message. He is now celebrated as offering "a masterful interpretation of the mind of a child," as our colleague Herbert Anderson remarks, "creating the kind of stories with which children often amuse themselves and strengthen their own self-respect." Might this essay do a just little of the 
same: amuse us and build our self-respect with a blend of what Anderson describes as Seuss's "nonsensical charm and sensible wisdom."2

Borrowing a format used by sociologist Bent Flyvbjerg in an article on case studies, I want to examine five common misunderstandings in the history and development of scholarship in practical theology that have preoccupied me in recent years: (1) practical theology is a marginalized discipline with a confused identity; (2) the problem with practical theology and theological education is the clerical paradigm; (3) practical and pastoral theology are interchangeable terms; (4) practical theology is impossible to define or, inversely, can be defined simply (e.g., study of the relationship between beliefs and practices); and (5) practical theology is largely, if not wholly, descriptive, interpretative, empirical, and not normative, theological, and in some cases (dare I say) Christian. I describe each misunderstanding and offer correctives, but my overall aim, despite my criticisms and corrections in each area, is to underscore that practical theology as a discipline has made significant progress and continues to have contributions to make to the academy and religious life more generally. Three decades of progress in the field, alongside complementary developments in other academic areas, affirm early intuitions in practical theology about the need for alternative ways of theological knowing and for further work in the discipline. Of course, to suggest that practical theology has arrived as a discipline is not to say that scholars have no work to do. Indeed, each misunderstanding lays out distinct arenas where further scholarship is requisite and, in some cases, urgent, especially if we want other scholars to pay attention.

\section{The Growing Appreciation for the Complexity of Practice}

At a practical theology conference earlier this year, a speaker began his paper as many of us do with comments about the sorry state of practical theology. He quoted Browning who describes practical theology as historically the "most beleaguered and despised of the theological disciplines." 3 Scholars are quick to label and reify practical theology as a "marginalized minority discipline"-

2 Herbert Anderson, Sense and Nonsense in the Wisdom of Dr. Seuss, New Theology Review (August 2001), 39.

3 Don S. Browning, Fundamental Practical Theology: Descriptive and Strategic Proposals, Minneapolis (Fortress) 1991, 3. 
Stephen Pattison's words in this case. ${ }^{4}$ We are even tempted to turn this grievance into a virtue, our "calling and destiny" as a colleague in pastoral care does. In a recent survey book, Robert Dykstra defiantly celebrates pastoral care's "fragile, sometimes fragmented identity on the margins," "outside the mainstream, off the beaten path, forgotten in the company of the downtrodden" and so forth. This "essential insecurity" results from the nature of the subject matter-the study of human persons and the divine, both of which are essentially unfathomable, unspeakable, and mysterious. So how can we accumulate knowledge? Our identity is found instead, he insists, in "not usually knowing who we are, in not always knowing what we are doing." Is this true or adequate?

My own early writings are replete with such characterizations even if I do not go as far as Dykstra in idealizing this. A 1990s article begins its disciplinary survey and redefinition by describing our "persistent identity crisis." ${ }^{6}$ I identify the proliferation of job titles in the United States as an example of our confusion (practical theology, pastoral theology, pastoral psychology, religion and personality, etc.). The discipline is trapped between modernity and postmodernity, arising out of the sciences as a quintessentially modern discipline just as modern scientific assumptions about universal truth and objectivity came under suspicion. As theology in general struggles to retain a place in the university (at least in the United States), so also is our position all the more precarious. If you want to write a comprehensive text in the field, I conclude, you must start here.

I no longer think this is the case. There is a certain truth to the portrait worth understanding. But a closer look at the reality behind the complaint suggests that our marginalization reflects a graver crisis in the academic understanding of practice that extends beyond our realm. That is, the problem is not ours alone. We simply took up its cause and, more important for my argument, time has proven this a worthy endeavor.

Seward Hiltner's 1958 Preface to Pastoral Theology offers a nice example of both the complaint and its merits. The book is riddled with frustrations about the disregard for practice in the academy, many of them lost in a quick reading because they are buried in the footnotes. He recognizes three operation-oriented areas-pastoral theology, educational and evangelistic theology, and ecclesiasti-

\footnotetext{
4 Stephen Pattison, The Challenge of Practical Theology. Selected Essays. London (Jessica Kingsley) 2007, 283.

5 Robert C. Dykstra, Images of Pastoral Care. Classic Readings, St. Louis (Chalice) 2005, 2, 3, 4 , and 6, emphasis in text.

6 Bonnie J. Miller-McLemore, The Subject and Practice of Pastoral Theology as a Practical Theological Discipline, in: Liberating Faith Practices: Feminist Practical Theology in Context, eds. Denise Ackermann and Riet Bons-Storm, Leuven, Netherlands (Peeters) 1998, 179.
} 
cal theology-but refuses the creation of a broader term like practical theology that encompasses them. Why? Because he fears that grouping the operational theologies under practical theology will just further ghettoize the study of ministerial and Christian practice. His testy footnotes illustrate his irritation at the deep "antipractical bias" in the academy. Repeatedly he decries the demeaning view of practical studies as "illegitimate theological children," a babe "clothed with diapers" rather than a genuine sibling. Long before power analysis became the intellectual lingua franca of today, he worries pastoral theology will "be the victim of an intellectual or theological heteronomy," regarded as "merely practical without the ability to make genuinely theological contributions."

In a word, Hiltner does not want the creation of a "discipline of "practical theology" as a "master perspective on acts and operations" to undermine his more fundamental contribution: that the "proper study of practice would illuminate theological understanding itself." Here lies what he believes is his allegiance with Friedrich Schleiermacher, who he identifies as the "one premodern writer" who "foreshadowed" this thesis. ${ }^{10}$

This just pushes my illustration one step further back: Schleiermacher faced the same biases in the eighteenth century. His effort to carve out space for theological study as knowledge oriented toward practice had a mixed reception in an academic system wedded to increasingly narrow understandings of truth. He himself saw the move from philosophical to historical to practical as the "most natural order," an order that represents "something of an ancient hierarchy," as contemporary scholar John Burkhart observes. Burkhart's own depiction of this classic hierarchy is laced with connotations of class and power: he compares the priority of the theoretical over the applied to the "modern university's pecking order, where mathematicians look down on physicists, who look down on engineers, who look down on contractors and janitors)."11 Schleiermacher's understanding of the value of practice was more nuanced than this, of course. But ultimately he could not control academic culture. In today's context where his understanding has been carried to its logical end, the "concourse

7 Seward Hiltner, Preface to Pastoral Theology, Nashville (Abingdon) 1958, 221, note 16; 217-219, notes 11 and 14.

$8 \mathrm{lbid} ., 24$. Elsewhere he resists its use in reference to a "theory of all the functions and operations of pastor and church" or a link between all the other fields and ministry $(20,23)$.

9 lbid., 47.

10 Ibid., 225, note 23.

11 John Burkhart, Schleiermacher's Vision for Theology, in: Practical Theology: The Emerging Field in Theology, Church, and World, ed. Don S. Browning, San Francisco (Harper \& Row) 1993 , 43. 
between theory and practice is a one-way street," "action does not really influence thought," and theological scholars rule over pastors and laity as the bottom feeders of theological knowledge. ${ }^{12}$

So, it is wise to know the politics out of which our discipline emerged. Initially at least, practical theology established itself in a hostile environment. But it is no longer necessary to start here or to bemoan our status. Times have changed and practical theologians have contributed to this. Fresh appreciation for religious practice, performance, case studies, the knowledge in the particular, material culture, and so forth has occurred across the academy. This is a defining moment for the discipline.

Examples abound. This plenary depends in its structure and content on an essay by the innovative Danish sociologist Bent Flyvbjerg, "Five Misunderstandings about Case-Study Research." Early in his career when he proposed doing an in-depth case study of urban politics, his teachers and colleagues discouraged him, saying he could not generalize from a single case, that such study is merely subjective-in essence that study of the particular holds minimal weight in the world of science. His essay is a step-by-step refutation of these judgments. Although it might seem that he is simply rehashing an old debate between qualitative and quantitative method, I think he takes on a deeper epistemological problem. He challenges the anti-practical bias that has ruled the Western academy, frustrating Hiltner and Schleiermacher among others.

Two aspects of Flyvbjerg's argument have relevance here: first, his challenge to the misunderstanding that "general, theoretical (context-independent) knowledge is more valuable than practical (context-dependent) knowledge" and, second, his comments about the limits of generalization. ${ }^{13}$ To dispute the former, he turns to phenomenological studies of how people learn. ${ }^{14}$ To move from a rule-based beginner to virtuoso expert requires more than general theories and the reduced formulas that comprise them. One must have experience with cases. In his words,

If people were exclusively trained in context independent knowledge and rules, that is, the kind of knowledge that forms the basis of textbooks and computers, they would remain at

12 Ibid., 53.

13 Bent Flyvbjerg, Five Misunderstandings about Case-Study Research, Qualitative Inquiry 12,2 (April 2006), 221.

14 This is an argument he develops more fully in Making Social Science Matte: Why Social Inquiry Fails and How it can Succeed Again, Cambridge (Cambridge University Press) 2001 and that draws on the Hubert Dreyfus and Stuart Dreyfus (with T. Athanasiou), Mind over Machine. The Power of Human Intuition and Expertise in the Era of the Computer, New York (Free Press) 1986. 
the beginner's level in the learning process. This is the limitation of analytical rationality: It is inadequate for the best results in the exercise of a profession, as student, researcher or practitioner. $^{15}$

He is not saying theories have no place. Rule-based knowledge is important for novices, it helps us program computers, but it does not represent the "highest goal of learning." Expert knowledge is context-dependent. It requires a dexterity of thought that draws from intimate familiarity with "several thousand concrete cases." 16

Second, Flyvbjerg questions the value of generalization itself. This is stated succinctly in his correction to a second misunderstanding that one cannot generalize from a single case. After showing that single cases have actually served well as the basis for generalization (e.g., Galileo, Freud), he makes the following qualification: "But formal generalization is overvalued as a source of scientific development."17 Sometimes the "most interesting phenomena" are "found in the most minute and most concrete of details." In-depth case study and narrative (without theoretical comment) are often "more useful" than "either factual 'findings' or the high-level generalizations of theory." 18

We know this colloquially when we say in English "a picture paints a thousand words." When I lecture and write, people consistently remember my personal stories more than the theoretical points. When tennis pro Tim Gallwey teaches tennis, he knows "images are better than words, showing better than telling, too much instruction worse than none." ${ }^{19}$ Flyvbjerg concludes his article reminding readers about an insight from Thomas Kuhn, which in my reading is quite damning of formal theology as it has developed in the last two centuries and supportive of the direction practical theology has gone: "A discipline without a large number of thoroughly executed case studies is a discipline without systematic production of exemplars, and ... a discipline without exemplars is an ineffective one." 20

Of course, researchers create theories. That is what we are trained to do. But "something essential may be lost by this summarizing," Flyvbjerg argues, an insight shaped by sociologist Pierre Bourdieu. ${ }^{21}$ In Outline of a Theory of Practice, Bourdieu questions the classificatory assumption of structural anthropology that

15 Flywbjerg (n. 13), 222.

16 Ibid., 222, 223.

17 Ibid., 228, emphasis in text.

18 Ibid., 237, 238.

19 Timothy Gallwey, The Inner Game of Golf, New York (Random House) 1998, 6-7.

20 Flyvbjerg (n. 13), 242.

21 Ibid., 240. 
rules for human behavior can be mapped out. The effort to theorize practice-"as one must, if one wants to study it scientifically"-subjects practice, which occurs in space and time, "to nothing less than a change in ontological status the more serious in its theoretical consequences because it has every chance of passing unnoticed."22 Theories are models or maps. But with maps, one risks mistaking the "model of reality" (e.g., theological doctrines) for the "reality of the model" (e.g., the richer, fuller concreteness of Christian life).

The idea that theoretical generalization has limited value is not new to Bourdieu or Flyvbjerg. It goes back to Aristotle, as Paul Ricoeur, Stephen Toulmin, and others remind us in their work on practical reason. Aristotle warned that in the "order of human affairs" we cannot "reach the same degree of precision ... as with, for example, the mathematical sciences." Ricoeur goes on to say, "Few ideas today are as healthy and as liberating as the idea that there is a practical reason but not a science of practice." ${ }^{23}$ This challenges Western Kantian assumptions that one can understand practical reason apart from desire and empirical context and "that the practical order is amenable to a system of knowledge, to a type of scientificity, comparable to the knowledge and the science required in the theoretical order." In actuality, practical reason belongs to the "intermediary" zone between "the science of immutable and necessary things and arbitrary opinion." ${ }^{24}$ Its logic is "fuzzy," in Bourdieu's words, in an entirely valid way. ${ }^{25}$

All this to say: a range of literature across the academy supports the early 1980 s intuition in practical theology about the need for more nuanced comprehension of practice. Right after Browning describes the discipline as beleaguered and despised in 1991, he says the "epistemological climate" is changing, and much has happened since then. Our story about where we stand two decades later needs to change accordingly. The first of the five misunderstandings about practical theology-that the discipline is marginal and in crisis-can therefore be revised as follows: Understanding knowledge as it arises in practice has become central to contemporary education. Practical theology's longstanding efforts to develop methods to study theology in practice and to teach toward

22 Pierre Bourdieu, Outline of a Theory of Practice, translated by Richard Nice, Cambridge (Cambridge Press) 1972, 120.

23 Paul Ricoeur, From Text to Action. Essays in Hermeneutics, II, Evanston, Illinois

(Northwestern University Press) 1991, 199. For another account that also locates the difference as one between Aristotle and Plato, see Stephen Toulmin, The Recovery of Practical Philosophy, American Scholar 57 (1988), 33-52.

24 Ricoeur (n. 23), 199, 205, emphasis in text.

25 Bourdieu (n. 22), 163. 
transformation contribute to this discussion and strengthen practical theology's position.

\section{Living with the Legacy of the Academic Paradigm}

When the history of theological education and the study of theology is told, they almost always refer to Edward Farley's treatise, Theologia, published during the 1980 s renaissance in practical theology. Since its publication, its influence is pervasive in practical theological works that try to situate themselves contextually before turning to their primary concern. ${ }^{26}$ Even historians, such as Randy Maddox, rely on Farley's portrait of the clerical paradigm when they describe modern developments, thereby perpetuating a second misunderstanding or oversimplification-that the problem with theological education and practical theology is the captivity of the clerical paradigm.

The clerical paradigm is a poor diagnosis for all that ails theological education. ${ }^{27}$ But it gets used all the time because it captures so clearly one problem with previous conceptions of practical theology. Framing theological education as concerned solely with technical tips and hints in ministry does a disservice to the complexity of ministry, faith, and practical theology. But the irony of the handy and unquestioned use of this heuristic tool is that it tends to blame the victim-clergy and their very real need to know how to practice ministry. In a telling footnote, Farley makes an important qualification that goes unnoticed. He says that in questioning the clerical paradigm he "wishes to avoid the impression that this is a questioning of either the validity of clergy education itself or of the validity of education for specific activities and skills." ${ }^{28}$ But this is precisely how the term has been interpreted. Its overuse has led us to devalue all things clerical or practical as lesser than all things academic, despite everyone's best intentions.

26 So widely used are his terms and explanations, they are "taken as self-evident", Barbara G. Wheeler, Introduction, in: Shifting Boundaries. Contextual Approaches to the Structure of Theological Education, eds. Barbara G. Wheeler and Edward Farley, Louisville (Westminster John Knox) 1991, 9.

27 I explore this in greater detail in “The 'Clerical Paradigm': A Fallacy of Misplaced Concreteness?, International Journal of Practical Theology 11, 2 (2007), 19-38.

28 Edward Farley, Theologia. The Fragmentation and Unity of Theological Education, Philadelphia (Fortress Press), 98, note 37. 
We need fresh ways to tell our history that do not demean our own interests. Correction requires two moves. First, we need fresh diagnoses. The clerical paradigm has become a mono-causal analysis that has led us to overlook other diagnoses. Fresh diagnosis suggests that theological education has focused largely on cognitive intelligence to its detriment, what I have called the academic paradigm or the cognitive captivity of theology. The problem, in other words, is not just the "clericalization," but an equally troubling "academization" of theology. Just as Farley argues that "in the clerical paradigm, theology ... is something for the clergy alone," it would be equally valid to say in the academic paradigm theology became something for the academy alone.

Philosopher Charles Taylor describes this problem as the "thrall of intellectualism." A longing for "timeless, aspatial formula" in imitation of the sciences still pervades the social sciences despite the efforts of major twentieth-century figures, such as Heidegger, Merleau-Ponty, and Wittgenstein. In a wonderful essay, "To Follow a Rule," Taylor shows the limits of a Western epistemology that presumes one knows by abstraction from bodies, distance from social relations, and the creation of inner cerebral representations of external reality. Following Wittgenstein, Taylor examines what is involved in "following a rule," such as directions given to an outsider on how to get to town. He concludes with Wittgenstein that an excess of knowledge beyond what can be articulated, represented, and theorized guides human understanding. Wittgenstein "stresses the unarticulated-at some points even unarticulable-nature" of the knowledge that shapes practice. ${ }^{29}$

This suggests a second correction to the misunderstanding that theological education went wrong when it focused on skills. We need to continue to try to understand the kind of knowledge needed by laity and ministers to perform or practice discipleship and ministry. Mental intelligence is important but not sufficient. The representations we make of the world-formula, rules, and so forth-are what Taylor describes as "only islands in the sea of our unformulated practical grasp on the world." To follow a rule requires "difficult and finely turned judgments," what Aristotle called phronesis. ${ }^{30}$

This idea is not new for practical theologians. Over the last three decades, people such as Bernard Lee and Thomas Groome have turned to Aristotle's typology of theoria (contemplative knowledge of truth), phronesis (knowledge of how to live well), and techne (knowledge of how to make things) in order to reclaim the viability of phronesis. Groome in particular challenges the classical

29 Charles Taylor, Philosophical Arguments, Cambridge (Harvard University Press) 1995, 167. 30 Ibid., 170, emphasis added, and 177. 
hierarchy of episteme over the other forms and advocates a holistic interrelationship between all three. ${ }^{31}$ However, he and others were more worried about techne-the triumph of technical rationality-than theoria or episteme. They seldom discussed the limits of episteme. Nor did they consider the value of techne and the inextricable interconnections between it and phronesis. Finally, they paid little attention to how the body and social world shape phronesis.

Unthinking dismissal of learning a craft as "mere know-how," as if such know-how is easy to master, overlooks its role in the greater pursuit of ministerial wisdom. Famous musicians do not cease doing scales. Learning to play an instrument requires a finely tuned dialectic between daily exercise and artistry. So techne has a place. In addition, phronesis requires embodiment and community. We can only understand this knowledge, as Bourdieu suggests, by gaining greater understanding of how our bodies and social milieu form our knowinghabitus in a much more concrete, grounded, particular, embodied, and relational framework than the more cerebral use of the term by Farley and others. Taylor goes so far as to say, "the rule exists only in the practice it animates, and does not require and may not have any express formulation," a suggestion that might seriously frustrate theologians who pursue systematic representation of theological rules. ${ }^{32}$

Thus, we need to quit insisting our discipline does not apply truths and determine what is involved in application. Repeatedly Browning paraphrased Richard Bernstein and Hans-Georg Gadamer to argue that in the practical wisdom necessary for ministry, "understanding, interpretation, and application are not distinct but intimately related." ${ }^{33}$ But then he and others paid little attention to application, a concern scholars such as Kathleen Cahalan, Robert Mager, Elaine Graham, and Chris Scharen have taken up in their work on theories of change, action theories, performance theories, and theories of learning. The discipline is only at the forefront of this challenging question of application.

We are far enough along, however, to correct the second oversimplification-that the problem with practical theology and theological education is the clerical paradigm-as follows: Short-hand use of the clerical paradigm to capture the plight of contemporary practical theology and theological education overlooks the equally troubling problem of intellectualism that distorts how religious knowledge is learned, conveyed, and practiced. Creative work on theological knowledge must grapple with how it is enacted in the world.

31 Thomas H. Groome, Sharing Faith. A Comprehensive Approach to Religious Education and Pastoral Ministry, New York (HarperCollins) 1991, 43, 47.

32 Taylor (n. 29), 178, emphasis added.

33 Browning (n. 3), 39, emphasis added. 


\section{Recognizing Practical and Pastoral Theology as Distinct}

In the wider scheme of this plenary, the third misunderstanding - that practical and pastoral theology are interchangeable terms - is minor and reflects my US context, but it has implications for my argument thus far about the value of the study of practice and the reform of theology itself. Whether scholars use pastoral or practical theology, they often share this common aim of articulating a dynamic theology that enriches the study of religious traditions through proximity to practice. But just because pastoral and practical theologies share this aim, are these terms commeasurable?

My desire for differentiation between them goes against the grain of the current discussion and even my own practice. ${ }^{34}$ Most British authors, for example, assume "either name will do," with increasing preference for practical theology as it has acquired recognition as a discipline. ${ }^{35}$ The Roman Catholic tradition often uses both terms to refer to various aspects of pastoral ministry rather than academic disciplines at all. In my own work, I have intermingled the terms, using the same paper on pastoral theology as public theology, for instance, for a book on pastoral care and counseling and for a presentation at a practical theology conference, simply changing terms as needed for each context. ${ }^{36}$ The disciplines do share theoretical assumptions and historical roots. Even though people politely ignore Hiltner's dislike of the term practical theology when they hail him as a founder, one could argue that his description of pastoral theology is not that different from common definitions of practical theology. So why distinguish them?

I have come to see their conflation as problematic despite their shared interest in lived experience. These terms are not as interchangeable now as in other periods, places, and traditions. In fact, I see value in accentuating rather than glossing over the distinctions. Use of these terms to refer to a single enterprise obfuscates one of practical theology's distinctive contributions as that discipline most concerned with mediating and integrating knowledge within

34 I explore this in greater detail in Also a Pastoral Theologian. In Pursuit of Dynamic Theology (Or: Meditations from a Recalcitrant Heat), Pastoral Psychology 59,6 (2010), 813-828.

35 For example, see Stephen Pattison/James Woodward, An Introduction to Pastoral and Practical Theology, in: The Blackwell Reader in Pastoral and Practical Theology, ed. James Woodward and Stephen Pattison, Madden, Mass. (Blackwell) 1999), 3.

36 Pastoral Theology as Public Theology. Revolutions in the 'Fourth Area,' Pastoral Care and Counseling: Redefining the Paradigms, ed. Nancy Ramsay, Nashville (Abingdon) 2004, 44-64. 
theological education and between seminary, congregation, and society. We also lose sight of the distinctive resources of twentieth-century pastoral theology as developed in the United States in rigorous conversation with modern psychoanalytic theory and psychology.

In the United States, pastoral theology is a sub-discipline of practical theology invested in care of persons. I situate my own work in pastoral theology within practical theology because of the latter's commitment to wider curricular and ministerial concerns. But I remain a pastoral theologian at heart, appreciative of its narrower focus on human angst and its appropriation of psychology. In using psychology, pastoral theology has sought a specificity of focus on particular persons and pain-the visceral and interior life of human beings-that is often absent from practical theology. Ultimately practical theology is insufficient for the work I want to do on individuals, development, personality dynamics, relationships, care, and theological anthropology.

Equally problematic, using pastoral and practical theology interchangeably has fostered a neglect of the insights of other subdisciplines, such as religious education, homiletics, and liturgics, and has given one area-pastoral theology-unwarranted privilege by virtue of name alone. Every practical theological sub-discipline, not just pastoral theology, has unique contributions to make to practical theology.

Finally, as Cahalan points out, pastoral theology has an especially troubled history within Roman Catholicism, which has not accorded it the status of an academic discipline to the same extent as has been true in Protestantism, despite advocates for this move, such as Karl Rahner. In the United States, the Catholic Church and its educational institutions currently lack the academic infrastructure to support such a disciplinary endeavor. Cahalan distinguishes practical from pastoral theology as the more viable of the two terms for the purpose of fostering such disciplinary development. ${ }^{37}$

All these problems suggest that the third misunderstanding, then, can be revised so it reads: Pastoral and practical theology refer to distinct academic endeavors. Because of the many-layered meanings of both terms, greater care in definition is needed. Whereas practical theology is integrative, concerned about

37 Kathleen A. Cahalan, Beyond Pastoral Theology. Why Catholics Should Embrace Practical Theology, in: Wilhelm Gräb and Lars Charbonnier, eds., Secularization Theories, Religious Identity and Practical Theology, Zurich/Berlin (Lit Verlag) 2009, 392-397; Pastoral Theology or Practical Theology? Limits and Possibilities, in: Keeping the Faith in Practice: Aspects of Catholic Pastoral Theology, ed. James Sweeney, Gemma Simmonds and David Lonsdale, London (SCM Press) 2010, 99-116. 
broader issues of ministry, discipleship, and formation, pastoral theology is personand pathos-centered.

\section{Practical Theology as Multivalent}

In one of the first 1980s anthologies, Farley concludes a brief history by saying "practical theology never has existed" as a discipline except as a "gleam in Schleiermacher's eye" and "does not now exist as a discipline." It is just a "generic term" for a cluster of subspecialties undeserving of an academic place. ${ }^{38}$ A few years later he begins another chapter debating whether practical theology is "a salvageable term." "So varied are the approaches and proffered definitions ... that it is not even clear what is under discussion." 39 Not much changed over a decade later when Johannes van der Ven starts a chapter in an international volume on practical theology saying, "some argue that practical theology has no methodology at all" and should not have one because it is "not a discipline," even as he attempts to counter this. ${ }^{40}$ A few years later, Bernard Lee says practical theology is not a "branch of theology (e.g., embracing homiletics, religious education, pastoral care, etc.)" but rather a kind of knowing or "a form of theological reflection." ${ }^{41}$ Elsewhere he says it is "a method-perhaps even a way of life" more than a discipline and eventually he resorts to the term phronetic theology to avoid the confusion entirely. ${ }^{42}$ More recently still, Terry Veling eschews definition as a lost cause, for practical theology is "less a thing to be

38 Edward Farley, Theology and Practice Outside the Clerical Paradigm, in: Practical Theology: The Emerging Field in Theology, Church, and World, ed. Don S. Browning, San Francisco (Harper \& Row) 1983, 32.

39 Edward Farley, Interpreting Situations: An Inquiry in the Nature of Practical Theology, in: Formation and Reflection. The Promise of Practical Theology, eds. Lewis S. Mudge and James N. Poling, Philadelphia (Fortress) 1987, 1.

40 Johannes A. van der Ven, The Empirical Approach in Practical Theology, in: Practical Theology: International Perspectives, eds. Friedrich Schweitzer and Johannes A. van der Ven, Frankfurt a. M. (Peter Lang) 1999, 323.

41 Bernard J. Lee, Politics and Economics in the Preaching of the Church. A New Testament Rendering of Phronesis, in: Poverty, Suffering, and HIV-AIDS. International Practical Theological Perspectives, eds. Pamela D. Couture and Bonnie J. Miller-McLemore, Cardiff (Cardiff Academic Press) 2003, 171.

42 Bernard J. Lee, Practical Theology: Its Character and Possible Implications for Higher Education, Current Issues in Catholic Higher Education 14,2 (1994), 26 and Practical Theology as Phronetic. A Working Paper from/for those in Ministry Education, APT Occasional Papers 1 (Winter 1998). 
defined than it is an activity to be done." ${ }^{43}$ One might see all this caution about practical theology as a discipline as a Roman Catholic proclivity, since all but Farley write in Catholic contexts. But in a 1991 entry on Protestant pastoral theology in the Dictionary of Pastoral Care and Counseling, Rodney Hunter and Russell Burck define practical theology as an "umbrella term" and conclude, "It has never been clear whether practical theology in this sense is or might become a discipline in its own right. Thus its relationship to pastoral theology has been either ambiguous or inconsequential." ${ }^{44}$

I recount this mini-history of definition not to disparage anyone but rather to show how far the discipline has come in the years since. Perhaps all new academic ventures begin cautiously. Practical theology certainly did. All the equivocating makes me ambivalent about assigning this literature to students who do not yet have the capacity to situate it. Although these scholars eventually contribute to the discipline's advancement, they welcome and devalue practical theology all at the same time. We should not be surprised that scholars of late now resort to a simplified shorthand to define practical theology as the discipline interested in the relationship between beliefs and practices.

I find both extremes problematic-either declaring practical theology un-definable as a discipline or easily defined. Developing a concise yet expansive definition is one of the more arduous but rewarding tasks that arose for me as a result of two involvements in the last several years. In 2003-2004, on behalf of the Graduate Department of Religion at Vanderbilt University, I co-chaired a planning grant aimed at creating a new Ph.D. program to prepare students for seminary teaching. There were times that year and over the years since our department received a grant for a Ph.D. curriculum in Theology and Practice when I tired of hearing colleagues and newly admitted students ask, "What is practical theology anyway?" This is not a simple question. Practical theology is not an easily defined category.

The sheer difficulty of definition, however, does not mean practical theology is an invalid or ill-conceived enterprise. Rather it underscores its complex and extended responsibilities. Eventually I articulated a more thorough answer, greatly helped by colleagues involved in a second enterprise, a consultation on Practical Theology and Christian Ministry that began in $2003 . .^{45}$ It gathered a

43 Terry A. Veling, Practical Theology: On Earth as It Is in Heaven, Maryknoll (Orbis) 2005, 4. 44 Rodney J. Hunter and Russell R. Burck, Pastoral theology, Protestant, in: Dictionary of Pastoral Care and Counseling, gen. ed. Rodney J. Hunter, Nashville (Abingdon) 1990, 867. 45 I explore this in greater detail in Practical Theology, in: Encyclopedia of Religion in America, eds. Charles H. Lippy and Peter W. Williams, Washington, D.C. (Congressional Quarterly Press) 2010,1739-1743. I also discuss this definition and use it to frame the edited book, The Wiley-Blackwell Companion to Practical Theology, London (Wiley/Blackwell) 2012. 
group of about twenty scholars and ministers from a variety of disciplines and traditions a couple times a year for several years. Our work together changed my understanding of practical theology in two fundamental ways. Discussing each other's research, syllabi, and accounts of ministry reoriented my view of practical theology's aim. Disciplinary expertise is always highly valued. But its ultimate aim lies beyond disciplinary concerns in the pursuit of an embodied Christian faith. Second and related to this, I gained a clearer picture of the multivalent nature of practical theology. Practical theology is a term with loaded and overlapping meanings. It appears in a broad array of spaces and places. It refers to at least four distinct enterprises with different audiences and objectives, the two just named: it is a discipline among scholars and an activity of faith among believers. And it has two other common uses: it is a method for studying theology in practice and it is a curricular area of subdisciplines in the seminary.

To state these four uses again in slightly different order, moving from practical theology's concrete embodiment to its specialized use, practical theology refers to an activity of believers seeking to sustain a life of reflective faith in the everyday, a method or way of analyzing theology in practice used by religious leaders and by teachers and students across the theological curriculum, a curricular area in theological education focused on ministerial practice and subspecialties, and, finally, an academic discipline pursued by a smaller subset of scholars to support and sustain these first three enterprises. Each understanding points to different spatial locations, from daily life to library and fieldwork to classroom, congregation, and community, and, finally, to academic guild and global context. The four understandings are connected and interdependent, not mutually exclusive, and reflect the range and complexity of practical theology today.

One benefit of this fourfold definition is its descriptive rather than prescriptive intent. It describes the varying contexts and ways people commonly use the term. Clarifying the various uses helps straighten out the confusion when people use the same term for equally valuable but different purposes. At the same time, a shared understanding of practical theology as a general way of doing theology concerned with the embodiment of religious belief in the day-to-day lives of individuals and communities unifies all four uses.

As this expansive yet focused definitional work suggests, practical theology is about so much more than the abbreviated mantras commonly used by scholars lately to define the discipline as the study of the "relationship between beliefs and practices" or the "correlation between the Christian tradition and contemporary experience." These are valid snapshots. But they leave much unsaid. Practical theology also redefines what constitutes theological knowledge or wisdom and seeks a theology for the masses. It explores the dissonance between professed beliefs and lived realities through the study of practice and serves a "critical 
function" or testing of the practical veracity of the claims of other theological disciplines, as Rahner argues. ${ }^{46}$ Practical theology is especially good at "interpreting situations," in Farley's words, or "descriptive theology" in Browning's model, partly because of its strong affinity with the social sciences and its close attention to the particular. It has a steadfast interest in concepts that overstep any one discipline, such as integration in theological education, formation and discipleship in religious communities, and vocation in the professions and over a lifetime. It insists that essential subject matters such as family, children, poverty, and sexuality cannot be understood adequately via one discipline alone but require a movement and conversation across areas of expertise and knowledge. Practical theology has long sustained a desire and an intention to weave webs of connection between theological disciplines and institutions in response to ministerial and social need, as Richard Osmer demonstrates in his recent work. ${ }^{47}$

This list of attributes is considerable. Each item represents a serious endeavor deserving the attention of a finely tuned academic discipline. Moreover, subdisciplines within practical theology as a curricular area also have their own distinctive contributions to make to practical theology and more generally. In other words, scholars have plenty of work to do in any one of these arenas.

Let me illustrate the kind of work needed by arguing for the value of just one of these many attributes-what Rahner called practical theology's critical function or testing of the divergence between stated belief and practice-and how this task in particular might be honed. ${ }^{48}$ In a recent essay, sociologist Mark Chaves does his own Flyvbjerg-like step-by-step debunking of a pervasive fallacy among religion scholars-what he calls the "religious congruence fallacy." Almost without fail, scholars in theology and religion presume that what people say they believe coheres with their actions. In reality, such congruence is rare. In fact, incongruence is far more common than congruence.

Chaves uses religious congruence in three ways-the systematic organization of beliefs, the coherence between beliefs and actions, and the consistency of belief and action over time and situation. His assertion that "people's religious ideas and practices are fragmented, compartmentalized, loosely connected, unexamined, and context dependent" is not surprising. That ideas and practice do not cohere is an uncontroversial claim among social scientists generally. What is

46 Karl Rahner, Practical Theology within the Totality of Theological Disciplines, Theological Investigations, Volume IX, Trans. Graham Harrison, New York (Herder and Herder) 1972, 104. 47 Richard R. Osmer, Practical Theology: An Introduction, Grand Rapids, MI (Eerdmans) 2008. 48 As argued above, others note the same problem. Taylor describes the "phronetic gap" between the formula and its enactment" (Taylor (n. 39), 177) and Bourdieu describes the divergence between the "maps" and the "beaten track" (Outline of a Theory of Practice, 2, 37-38). 
surprising, what makes Chaves's article important, is his second claim that religion scholars so often look the other way: "this established knowledge does not inform our research and thinking as centrally and deeply as it should .... we often interpret our research findings in ways that presuppose a congruence that we know is not generally there. ${ }^{39} \mathrm{He}$ shows how deep the desire for religious congruence runs, on the one hand, and how unlikely it is that any kind of theology might capture the complexity of faith practice, on the other hand.

Even though Chaves's ultimate aim is to correct this fallacy, his illustrations of the ubiquity of incongruence are fascinating. One study shows, for example, that "intrinsically religious people do not act in more prosocial ways than anyone else, but they think they do, or should, or would." ${ }^{50}$ Religious confession and action are highly situational and instrumental. So pro-athletes perform rituals to enhance performance but do not skip rigorous workouts, divine healers supplement prayer with medical intervention, Native Americans pray for rain in the rainy season, and so forth. "If we want to predict someone's behavior," another study suggests, "'we are better off knowing where they are rather than who they are" or, restated, "the religious situation is more important than the religious disposition.",51

This certainly undercuts assumptions about virtue, character ethics, and the formative power of religious communities. It also goes against the presumption that religion makes us better. This does not mean religious communities should abandon recitation of creeds or efforts to form people in faith. It simply points out the complexities. Congruence requires sophisticated capacities for cognitive reflection, cohesive social control, and internalization not easily sustained by individuals or communities. Recognizing that causal links between belief and behavior are complicated also tempers demonization and idealization of religion's social impact among atheists and religious fanatics alike. Religion seldom deserves either complete blame or total credit. Human belief and action are more complicated than this.

Chaves's suggestion for the researcher is not, however, to hunker down and just study practices, as he himself did initially. He has changed his mind and argues instead for a middle ground. Two suggestions for correcting the religious congruence fallacy stand out for practical theologians. The first simply confirms that we are going in the right direction: "we should move toward a more deeply situational model of religious influence." A second idea is less apparent in our work and worth heeding: Instead of the overwhelming focus on beliefs, we might

49 Mark Chaves, Rain Dances in the Dry Season: Overcoming the Religious Congruence Fallacy, Journal for Scientific Study of Religion 49,1 (2010), 2.

50 ibid. 5.

51 Ibid. 4, emphasis in the text. 
take other mental states more seriously: "We also have perceptions, expectations, feelings, wishes, attitudes, and intentions, all of which might shape action." In fact, beliefs are the "least predictive of behavior." 52

We can now return to the primary question of practical theology's definition as a discipline and reformulate the fourth misunderstanding-that practical theology is impossible to define or, inversely, can be defined simply-so it reads as follows: Difficulty in explaining practical theology need not undercut its value. It is a discipline but it is not only a discipline. It is a multivalent term with distinctive and varying uses. Differentiating its uses will clarify confusion and foster refinement in specific areas.

\section{Constructive Theological Contributions}

The final misunderstanding-that practical theology is largely, if not wholly, empirical, descriptive, interpretative, and not normative, theological, and in some cases (dare I say) Christian-is less a misunderstanding than a lapse. My response is more a reminder of what we have understood but forgotten than a correction. When Hiltner urged the "proper study of practice" in the 1950s, he said it had the potential to "illuminate theological understanding itself." $53 \mathrm{We}$ simply need to come through on this promise.

Others have also encouraged practical theology to claim its constructive theological contribution more boldly, even if the "potent, exotic" vision that emerges from the "insider perspective" of Christian faith threatens to return us to a marginal position in Pattison's words. ${ }^{54}$ Pattison and others, such as Kathryn Tanner and Rowan Williams, recognize that for theology to have an intellectual place universities in general must reconstitute themselves as invested in serving society. If universities saw knowledge as essential to practical social change rather than as merely an end in itself, if they sought to reach beyond the "narrow functionalism and economism that so often dominate," then inclusion of Christian theology "in all its constructive aspects" (and other confessional religious traditions and perspectives) would be "less anomalous," as Tanner argues, and more constitutive of the academic mission. ${ }^{55}$

52 lbid, 11-12.

53 Hiltner (n. 7), 47.

54 Pattison (n. 4), 283.

55 Rowan Williams, Oxford University Commemoration Day Sermon, TAO XLIV, 1 (Winter 2007), 29, 30; Kathryn Tanner, Theology and Cultural Contest in the University, in: Religious Studies, 
Of course, we must have something interesting to say: "The primary justification for inclusion is the ability to produce an interestingly different angle on life." ${ }^{56}$ This is where practical theologians face a challenge. No one says practical theology is not normative, constructive, or Christian. But do we have something theologically interesting to say? For decades, practical theologians have argued that attention to practice has a yield for theology but specifying this or even getting around to it has been difficult. If practical theology has been partly about transforming academic theology, then it has to show what it has contributed to theology as theology.

Our lapse arises more in the tone, structure, and nature of our work, socialized and honed within academic settings that exclude normative and constructive conviction. The "highly refined process ... of dissociation and dislocation" in the theological academy, Willie Jennings argues, is not a problem of the split between theory and practice, classical and practical disciplines, academy and church, or even abstract and concrete thinking. Instead he observes a fundamental "resistance of theologians to think theologically about their identities," a posture that would demand that we relate to others differently. Socialization in capacities to "clarify, categorize, define, explain, interpret" reflects colonialist patterns of reflection done at "commanding heights" from those forced to submit to the conquering other. Such intellectual socialization avoids the "transformation not only of ways of thinking but ways of life" that the "trajectory of the incarnate life of the Son of God" provokes. ${ }^{57}$

Research in practical theology often follows a pattern latent in case study: we tack theology on at the end. Theology appears as the final step in case analysis. We hesitate to move beyond objective, empirical, fact-finding research to theological insight and disclosure. This hesitancy is understandable. Many of us survive in institutions that question Christian belief. There are obvious dangers in confessional and Christian-centric research of parochialism, exclusivism, moralism, and so forth that others have already analyzed extensively. Our safety, security, and excellence lies in our careful detailed empirical work. Less clear is how our descriptive and interpretative work is theological from the beginning, how what we see and describe is shaped by specific confessional sensitivities and religious context. Moreover, description is only the first step in the hermeneutical circle that contributed to practical theology's revitalization. Description and interpreta-

Theology, and the University: Conflicting Maps, Changing Terrain, eds. Linell E. Cady and Delwin Brown, New York (State University of New York Press) 2002, 203, 204.

56 Tanner (n. 55), Theology and Cultural Contest in the University," 206.

57 Willie James Jennings, The Christian Imagination: Theology and the Origins of Race, New Haven (Yale University Press) 2010, 7, 8, emphasis in the text. 
tion by themselves are insufficient. Practical theology's objective is both to understand and to influence religious wisdom in congregations and public life more generally. Many would argue that practical theology is, in fact, not complete without a move from description to normative construction and action.

Sometimes theological claims are at odds with science. Science wants to know how religion and spirituality are useful (or not), how they contribute to (or prevent) the advancement of individuals and civilization. Religious confessionChristian and otherwise-relativizes and ultimately refutes such instrumental interpretation (e.g., spirituality, meditation, church-going, etc. are good for our mental health, marriage, recovery from illness, or other relative ends). Most religions argue that life is not all about humans, individual happiness, and social success; it is about reverence, gratitude, service, glorifying God, mutual love, abundant life, or some other sacred and transcendent end that is sometimes completely inarticulatable and beyond human limits.

Reformulating the final misunderstanding - that practical theology is largely, if not wholly, descriptive, interpretative, empirical-sounds a little like stating the obvious: practical theology is in fact theology. However, there are benefits of a more explicit correction as follows: As theology, practical theology is normative. It makes demands on those who practice it to live by the sacred and transcendent convictions it professes. Greater clarity about our theological and not just our practical contribution is one of our challenges but success in this realm will advance the discipline and its value for religious communities and the common good.

\section{Concluding Thoughts}

When the boy in Seuss's story has to decide what to report from his walk home from school along Mulberry Street, he must contend with his dad, a formidable realist:

\footnotetext{
"But when I tell him where I've been

And what I think I've seen,

He looks at me and sternly says,

"Your eyesight's much too keen.

"Stop telling such outlandish tales.

Stop turning minnows into whales."
}

Sometimes science and academic theology function a little like this parent, closed off to seeing life fully. The hegemony of science in its narrowest sense, 
the valuation of episteme over phronesis, and the view of theology as theoria or scientia cannot be transformed overnight. Hiltner can be faulted, as Hunter says, for not going far enough to clarify the "full epistemological import" of his claims about practical knowledge or in explaining how experience provides knowledge. But he at least laid groundwork on which others built. ${ }^{58}$ In the last quarter century practical theology has disrupted the space occupied by academic theology, becoming a kind of thorn in the flesh of theology abstracted from life. Like the liberation theologies that have had a steady influence since the 1960s, practical theology has been about taking theology out to the streets and about using what it has learned from going out to assess the adequacy of biblical, historical, and doctrinal claims. This work has disturbed conventional boundaries and redefined what theology is, how it is done, and who does it. ${ }^{59}$

Reassessing the five misunderstandings about practical theology confirms its vitality, relevance, and contribution as a discipline. This optimism should not be mistaken, however, as a reason to rest on our laurels. Prejudice, ignorance, confusion and misunderstanding of practical theology abound. Internal to the discipline, sloppy scholarship and a failure to convey clearly the fruits of our discoveries to a wider intellectual public remain a problem. Each of the five misunderstandings suggests areas deserving further research and development. We need to produce the kind of scholarship and teaching that makes our intellectual contribution clear or get left behind as scholars in other disciplines move into terrain and topics previously our own.

Of course, restoring practical theology as a discipline is not a sufficient end unto itself. Its greater aim is to foster richer material understandings of embodied theology so that those who practice ministry and pursue lives of Christian faith will have a greater sense of their theological and religious vocation. Practical theology has always been and remains far more than an academic endeavor. It has been about returning theology to the people. As a discipline, practical theology is indeed secondary to the work and practice of most Christians and scholars. But as a way of faithful discipleship and as way of doing theology in daily life, it is fundamental to Christian faith and to all areas of theological study and practice.

58 Rodney I. Hunter, A Perspectival View of Pastoral Theology: A Critique of Hiltner's Theory, Journal of Pastoral Care 4 (1985), 20.

59 See Bonnie J. Miller-McLemore, Christian Theology in Practice. Discovering a Discipline, Grand Rapids (Eerdmans) 2012. 


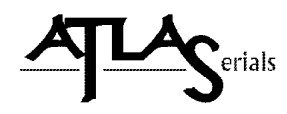

Copyright and Use:

As an ATLAS user, you may print, download, or send articles for individual use according to fair use as defined by U.S. and international copyright law and as otherwise authorized under your respective ATLAS subscriber agreement.

No content may be copied or emailed to multiple sites or publicly posted without the copyright holder(s)' express written permission. Any use, decompiling, reproduction, or distribution of this journal in excess of fair use provisions may be a violation of copyright law.

This journal is made available to you through the ATLAS collection with permission from the copyright holder(s). The copyright holder for an entire issue of a journal typically is the journal owner, who also may own the copyright in each article. However, for certain articles, the author of the article may maintain the copyright in the article. Please contact the copyright holder(s) to request permission to use an article or specific work for any use not covered by the fair use provisions of the copyright laws or covered by your respective ATLAS subscriber agreement. For information regarding the copyright holder(s), please refer to the copyright information in the journal, if available, or contact ATLA to request contact information for the copyright holder(s).

About ATLAS:

The ATLA Serials (ATLAS $®$ ) collection contains electronic versions of previously published religion and theology journals reproduced with permission. The ATLAS collection is owned and managed by the American Theological Library Association (ATLA) and received initial funding from Lilly Endowment Inc.

The design and final form of this electronic document is the property of the American Theological Library Association. 